\title{
Editorial
}

\section{Sir Charles Oatley}

(Frome (Somerset) 2 February 1904 - Cambridge 11 March, 1996)

The first commercial scanning electron microscope, the Stereoscan, was put on sale in 1965 by the Cambridge Instrument Co., largely as a result of the pioneering efforts of Charles Oatley, who died at his Cambridge home a few weeks ago. Such instruments had been adumbrated, and experimental models built, in the years before and during the Second World War, notably by von Ardenne, but none of these was destined for success.

Oatley's early years were spent at Cambridge, where he read Natural Sciences (Physics) and incidentally was captain of the University swimming team. However, perhaps the most significant fact to be recorded about that period is that he came into contact with E.V. Appleton, who later recruited him into the Physics Department at King's College London, to which Appleton had moved in the meantime. During the wartime years, he worked on the development of radar, as it came to be called, and made major contributions to the technique. His role was to build up a Measurements Group, and the experience gained with a wide range of electronic components was undoubtedly of great value for the future.

In 1945, he returned to Cambridge, to the Engineering Department, not the Cavendish, where he modernized the teaching of electrical engineering (converting "electric signalling" into "electronics") and later created a research group, at best to develop the scanning electron microscope or, at worst, to demonstrate conclusively that no further time should be wasted on it. In his own words, "The design and construction work would provide an excellent training in research; we should learn a great deal about the practical side of electron optics, which would be useful in other projects; and we should certainly end up with a microscope which gave results of some kind, which might or might not justify further work. I decided to go ahead" [1]. A succession of research students, the first of whom - Dennis McMullan - has written about Sir Charles for Nature [2], advanced the project to the point at which the Stereoscan reached the market. After a slow start, orders for this new instrument came pouring in and - after a further pause - Oatley's role was recognized by a host of honours, among them election to the Royal Society in 1969, and the award of the Royal medal, the Faraday medal, the Duddell medal, the James Alfred Ewing Medal and the Howard Potts prize; he received several honorary degrees and honorary fellowships and in 1974, was knighted.

As well as papers on specific aspects of the microscope, Oatley contributed to a major survey of the SEM [3], which for many years remained the standard text on the subject; he later published the first (and only) volume of a planned treatise on the same subject [4]. He later wrote a number of accounts of the development of the instrument [1,5], in which the work of his predecessors was, characteristically, praised above his own: "Von Ardenne was the true father of the scanning 
electron microscope, who had all the right ideas. His misfortune was to have worked at a time when experimental techniques had not advanced quite far enough to enable him to bring these ideas to full practical fruition", wrote Oatley in 1982. Perhaps so, but the "true father" of the SEM that we know today is surely Oatley himself. He retired in 1971 but continued to give his mind to the SEM, as a number of late publications attest. Even so, his beautiful garden and fine roses benefited from the increased time and attention he could then spare them.

So much for the scientist, what of the man? The foregoing quotation from one of his historical papers is indicative. A man of strong character, who knew what he wanted to do and succeeded in doing it, but whose human qualities were such that he was highly esteemed by his research students, some of whom became his colleagues and many of whom achieved positions of great .eminence; one (A.N. Broers) now occupies the Chair in the Cambridge University Engineering Department formerly occupied by Sir Charles. One-day meetings were organized for his 80th and 90th birthdays and almost all his former research students and numerous other friends and colleagues returned to Cambridge to be present. Nostalgia, respect and real affection filled the air. It is perhaps fanciful to suggest that one might have guessed as much from his name but any reader of Trollope or Jane Austen would expect a Sir Charles Oatley to be among the heroes, not the villains! I am proud to have known him and to have enjoyed his friendship.

On behalf of the Société Française des Microscopies, I offer very sincere condolences to Enid, his widow, and to his sons John and Michael.

\section{References}

[1] Oatley C.W., The early history of the scanning electron microscope, J. Appl. Phys. 53 (1982) R1-R13.

[2] McMullan D., Charles Oatley (1904-96), Nature 380 (1996) 670.

[3] Oatley C.W., Nixon W.C. and Pease R.F.W., Scanning electron microscopy, Adv. Electron. Electron Phys. 21 (1965) 181-247.

[4] Oatley C.W., The Scanning Electron Microscope. Part I. The Instrument (University Press, Cambridge, 1972).

[5] Oatley C.W., McMullan D. and Smith K.C.A., The development of the scanning electron microscope. In "The Beginnings of Electron Microscopy", Adv. Electron. Electron Phys. Suppl. 16 (1985) 443-482.

Peter Hawkes

CNRS, Toulouse 